\title{
APPLICATION OF A REALISTIC MATHEMATICAL APPROACH TO IMPROVE THE CAPACITY OF THE PROBLEM MATHEMATIC STUDENTS CLASS VII SMP NEGERI 3 SATU ATAP KUALA
}

\author{
Elva Bonica*, Hasratuddin \\ Program Studi Pendidikan Matematika, FMIPA, Universitas Negeri Medan, \\ Jl. Willem Iskandar Psr. V Medan Estate, Medan, Indonesia, 20221 \\ "E-mail : Elvabonica@gmail.com
}

\begin{abstract}
The purpose of this research is to know the improvement of students' mathematical problem solving ability after applying realistic mathematics approach of class VII-b SMP Negeri 3 Satu Atap Kuala and to describe that realistic mathematics approach is better than conventional learning. The subjects of the study were Class VII-b SMP Negeri 3 Satu Atap Kuala which amounted to 40 students. The object of this research is to improve students' mathematical problem solving ability through realistic mathematics approach class VII-b SMP Negeri 3 Satu Atap Kuala. This type of research is a classroom action research. In this study consists of two cycles, where at the end of each cycle is given a problem-solving test to determine students' mathematical problem solving abilities. The question form for each test is a description. The first procedure in this study was to give an initial skill test to class VII-b (to be studied) and class VII-a, in order to see students' early mathematical problem-solving abilities. The two held a lesson with the application of a realistic mathematical approach with rectangular subjects in class VII-b. Before the first action is given a preliminary test to determine the initial ability and early difficulty of students. From the preliminary results of the tests, the mean grade of grade VII-b is 53.75 and class VII-a is 53.625. After giving the action through realistic mathematics approach in cycle 1 in class VII-b, the mean value of problem solving ability test I was 70.83 with the number of students who have reached the classical learning completeness level of 24 students (60\%) and conventional class VII -a is 60.17 with the number of students reaching the classical learning level of 9 students (22.5\%). While after the improvement of cycle I in cycle II, the average value of problem solving test of class II VII-b is 81.83 with the number of students reaching the classical learning level of 37 students (92,5\%) and class VII-a is 69.08 with the number of students reaching the classical learning level as much as 19 students (47,5\%). Based on the results of this study indicate that by applying realistic mathematics approach on rectangular subjects in class VII-b SMP Negeri 3 Satu Atap Kuala can improve the problem solving ability of mathematical students and classes that are given a realistic mathematical learning approach is better than the class that is given conventional learning .
\end{abstract}

Keywords: Problem Solving Abilities, Realistic Mathematical Approach

Elva Bonica, Hasratuddin, Application of A Realistic Mathematical Approach to Improve The Capacity of The Problem Mathematic Students Class VII SMP Negeri 3 Satu Atap Kuala. Jurnal Inspiratif, Vol. 4, No. 1 April 2018. 


\title{
PENERAPAN PENDEKATAN MATEMATIKA REALISTIK UNTUK MENINGKATKAN KEMAMPUAN PEMECAHAN MASALAH MATEMATIS SISWA KELAS VII SMP NEGERI 3 SATU ATAP KUALA
}

\begin{abstract}
ABSTRAK
Tujuan penelitian ini adalah untuk mengetahui peningkatan kemampuan pemecahan masalah matematis siswa setelah diterapkan pendekatan matematika realistik kelas VII-b SMP Negeri 3 Satu Atap Kuala dan untuk mendeskripsikan bahwa pendekatan matematika realistik lebih baik daripada pembelajaran konvensional. Subjek penelitian adalah kelas VII-b SMP Negeri 3 Satu Atap Kuala yang berjumlah 40 siswa. Objek penelitian ini adalah untuk meningkatkan kemampuan pemecahan masalah matematis siswa melalui pendekatan matematika realistik kelas VII-b SMP Negeri 3 Satu Atap Kuala T.A 2016/2017. Jenis penelitian ini adalah penelitian tindakan kelas. Dalam penelitian ini terdiri dari dua siklus, dimana di akhir setiap siklus diberikan tes kemampuan pemecahan masalah untuk mengetahui kemampuan pemecahan masalah matematis siswa. Bentuk soal untuk setiap tes adalah uraian. Prosedur yang pertama pada penelitian ini adalah memberi tes kemampuan awal kepada kelas VII-b (yang akan diteliti) dan kelas VII-a, guna untuk melihat kemampuan pemecahan masalah matematis awal siswa. Kedua mengadakan pembelajaran dengan penerapan pendekatan matematika realistik dengan pokok bahasan segi empat di kelas VII-b. Sebelum tindakan dilakukan terlebih dahulu diberikan tes awal untuk mengetahui kemampuan awal dan kesulitan awal siswa. Dari hasil tes awal yag diperoleh menunjukkan bahwa nilai rata - rata kelas VII-b adalah 53,75 dan kelas VII-a adalah 53,625. Setelah pemberian tindakan melalui pendekatan matematika realistik pada siklus 1 di kelas VII-b, nilai rata - rata tes kemampuan pemecahan masalah I adalah 70,83 dengan jumlah siswa yang telah mencapai tingkat ketuntasan belajar klasikal sebanyak 24 siswa (60\%) dan kelas konvensional VII-a adalah 60,17 dengan jumlah siswa yang mencapai tingkat belajar klasikal sebanyak 9 siswa (22,5\%). Sedangkan setelah dilakukan perbaikan dari siklus I pada siklus II, nilai rata - rata tes kemampuan pemecahan masalah II kelas VII-b adalah 81,83 dengan jumlah siswa yang mencapai tingkat belajar klasikal sebanyak 37 siswa (92,5\%) dan kelas VII-a adalah 69,08 dengan jumlah siswa yang mencapai tingkat belajar klasikal sebanyak 19 siswa (47,5\%). Berdasarkan hasil penelitian ini menunjukkan bahwa dengan menerapkan pendekatan matematika realistik pada pokok bahasan segi empat di kelas VII-b SMP Negeri 3 Satu Atap Kuala dapat meningkatkan kemampuan pemecahan masalah matematis siswa dan kelas yang diberi pembelajaran pendekatan matematika realistik lebih baik daripada kelas yang diberi pembelajaran konvensional.
\end{abstract}

Kata Kunci : Kemampuan Pemecahan Masalah, Pendekatan Matematika Realistik

\section{PENDAHULUAN}

Pendidikan merupakan hal yang terpenting dalam kehidupan manusia, ini berarti bahwa setiap manusia berhak mendapat dan berharap untuk selalu berkembang dalam pendidikan. Dunia pendidikan akan memberikan kontribusi yang besar terhadap pengembangan sumber daya manusia yang memiliki kemampuan pemecahan masalah yang handal untuk menjalani masa depan yang penuh tantangan. Seperti yang tercantum dalam UU No. 20 Tahun 2003 tentang Sistem Pendidikan Nasional (dalam Trianto, 2011: 1):

Pendidikan Nasional berfungsi mengembangkan kemampuan dan membentuk watak serta peradaban bangsa yang bermartabat dalam rangka

Elva Bonica, Hasratuddin, Application of A Realistic Mathematical Approach to Improve The Capacity of The Problem Mathematic Students Class VII SMP Negeri 3 Satu Atap Kuala. Jurnal Inspiratif, Vol. 4, No. 1 April 2018. 
mencerdaskan kehidupan bangsa. Pendidikan bertujuan untuk mengembangkan potensi peserta didik agar menjadi manusia yang beriman dan bertakwa kepada Tuhan Yang Maha Esa, berakhlak mulia,sehat, berilmu, cakap, kreatif, mandiri, dan menjadi warga Negara yang demokratis serta bertanggung jawab.

Matematika merupakan salah satu ilmu dasar yang sangat diperlukan siswa untuk mengembangkan kemampuan berpikir logis, sistematis, mengkomunikasikan gagasan, dan memecahkan masalah dalam kehidupan sehari-hari serta dapat menumbuhkan penalaran siswa dan sangat dibutuhkan dalam perkembangan ilmu pengetahuan dan teknologi. Ada banyak alasan tentang perlunya siswa belajar matematika. Menurut Cornelius (dalam Abdurrahman, 2009: 253) mengemukakan bahwa:

Lima alasan perlunya belajar matematika karena matematika merupakan (1) sarana berpikir yang jelas dan logis, (2) sarana untuk memecahkan masalah kehidupan sehari-hari, (3) sarana mengenal pola-pola hubungan dan generalisasi pengalaman, (4) sarana untuk mengembangkan kreativitas, dan (5) sarana untuk meningkatkan kesadaran terhadap perkembangan budaya.

Besarnya peran matematika tersebut menuntut siswa harus mampu menguasai pelajaran matematika. Terutama siswa dituntut dalam menyelesaikan masalah matematika. Karena dengan pengetahuan yang dimiliki siswa dalam menyelesaikan masalah matematika maka akan memberikan kesempatan kepada siswa untuk mengaplikasikan pengetahuan yang mereka miliki untuk memahami masalah dalam kehidupan nyata. Namun pada kenyataannya, tingginya tuntutan untuk menguasai matematika tidak berbanding lurus dengan hasil belajar siswa. Banyak siswa yang memiliki hasil belajar yang rendah sehingga berpengaruh terhadap prestasi siswa. Siswa rendah dalam kemampuan penalaran dan kemampuan pemecahan masalah matematika (Rizqi dan Surya, 2017).
Kemampuan adalah potensi yang dimiliki oleh seseorang dalam menguasai keterampilan bawaan atau hasil latihan yang digunakan unt uk melakukan sesuatu yang akan dicapai. Sementara memecahkan masalah matematika merupakan kegiatan untuk memecahkan masalah cerita, memecahkan masalah yang tidak rutin, menerapkan matematika untuk kehidupan sehari-hari atau keadaan lainnya (Hasanah \& Surya, 2017). Kemampuan pemecahan masalah perlu dikendalikan oleh siswa untuk mendorong mereka menjadi pemecah masalah yang baik, yang mampu menghadapi masalah kehidupan sehari-hari (Amalia, Surya, \& Syahputra, 2017). Menurut Tambychika, dkk (dalam Paranginangin \& Surya, 2017) bahwa pemecahan masalah merupakan salah satu aspek utama dalam kurikulum matematika yang diperlukan siswa untuk menerapkan dan mengintegrasikan banyak konsep-konsep matematika dan keterampilan serta membuat keputusan. Namun, siswa dilaporkan memiliki kesulitan dalam masalah matematika pemecahan Menurut Sadiq dan Sumarno (dalam Surya, dkk, 2013) kemampuan pemecahan masalah matematika siswa rendah juga disebabkan oleh proses pembelajaran matematika di kelas kurang meningkatkan kemampuan berpikir tingkat tinggi dan kurang berkaitan langsung dengan kehidupan nyata seharihari. Pentingnya pemecahan masalah ini juga diungkapkan oleh Beigie (dalam Surya, Putri \& Mukhtar, 2017) bahwa melalui pemecahan masalah, siswa dapat belajar tentang memperdalam pemahaman mereka tentang konsep-konsep matematika dengan bekerja melalui isuisu yang dipilih dengan hati-hati yang menggunakan aplikasi matematika untuk masalah nyata.Hal senada diungkapkan oleh Eysenck (dalam Amalia, Surya, \& Syahputra, 2017) bahwa pemecahan masalah merupakan indikator beberapa negara dalam menentukan kemampuan siswa untuk memahami konsep-konsep dan ide-ide belajar. keterampilan pemecahan masalah akan berkembang dengan cepat jika masalah pemecah

Elva Bonica, Hasratuddin, Application of A Realistic Mathematical Approach to Improve The Capacity of The Problem Mathematic Students Class VII SMP Negeri 3 Satu Atap Kuala. Jurnal Inspiratif, Vol. 4, No. 1 April 2018. 
mendapatkan pengalaman baru dari aktivitas mereka.

Pentingnya kemampuan pemecahan masalah baik dikemukakan oleh Hudoyo (dalam Batubara, dkk, 2017) yang menyatakan bahwa pemecahan masalah adalah sesuatu yang penting dalam pembelajaran matematika di sekolah, karena, antara lain: (1) Siswa menjadi terampil memilih informasi yang relevan, kemudian menganalisanya dan kemudian diperiksa hasil; (2) kepuasan intelektual akan datang dari dalam, yang merupakanmasalah intrinsik; (3) Potensi intelektual siswa meningkat; (4) Siswa belajar bagaimana melakukan penemuan melalui proses melakukan penemuan. Maka dari itu kemampuan pemecahan masalah ini harus mendapat perhatian khusus, mengingat peran yang sangat strategis dalam mengembangkan potensi intelektual siswa.

Pendekatan pembelajaran yang dapat meningkatkan pemecahan masalah matematis siswa yaitu dengan menerapkan Pendekatan Matematika Realistik. Dalam pembelajaran matematika realistik, masalah realistik tidak hanya masalah yang nyata (real) yang dapat muncul dari masalah kontekstual atau kehidupan sehari-hari. Tetapi suatu masalah disebut realistik jika masalah tersebut dapat dibayangkan atau nyata dipikiran siswa. Sejalan dengan Wijaya (2012:20-21) bahwa:

"Suatu pengetahuan akan menjadi bermakna bagi siswa jika proses pembelajaran dilaksanakan dalam suatu konteks atau pembelajaran menggunakan permasalahan realistik. Suatu masalah realistik tidak harus selalu berupa masalah yang ada di dunia nyata (real word problem) dan bisa ditemukan dalam kehidupan sehari-hari siswa. Suatu masalah disebut realistik jika masalah tersebut dapat dibayangkan (imagineable) atau nyata (real) dalam pikiran siswa".

\section{METODE PENELITIAN}

Penelitian ini dilaksanakan di SMP Negeri 3 Satu Atap Kuala kelas VII-b. Waktu penelitian ini dilaksanakan pada semester genap Tahun Ajaran 2016/2017. Penentuan waktu penelitian ini mengacu pada kalender akademik sekolah. Subjek dalam penelitian ini adalah siswa kelas VIIb yang berjumlah 40 orang. Objek dalam penelitian ini adalah upaya meningkatkan kemampuan pemecahan masalah matematis siswa kelas VII-b SMP Negeri 3 Satu Atap Kuala dengan menerapkan Pendekatan Matematika Realistik Jenis penelitian ini adalah Penelitian Tindakan Kelas (Classroom Action Research) dengan menerapkan Pendekatan Matematika Realistik, dilakukan dengan tujuan meningkatkan kemampuan pemecahan masalah matematis siswa. PTK bersifat luwes dan mudah diadaptasi sehingga cocok digunakan dalam rangka pembaharuan kegiatan pembelajaran di kelas. PTK juga berperan dalam mengembangkan keterampilan mengajar yang bertolak dari kebutuhan untuk menanggulangi berbagai persoalan aktual yang dihadapi terkait dengan pembelajaran terutama akan sangat terasa bagi peneliti. Sebagai calon guru, itulah beberapa alasan mengapa peneliti memilih penelitian tindakan kelas.

\section{HASIL PEMBAHASAN}

Pemecahan masalah dalam matematika melibatkan metode dan cara penyelesaian yang tidak standar dan tidak diketahui terlebih dahulu. Rosli dkk (2013:54) berpendapat bahwa "Pemecahan masalah dan telah menjadi kegiatan kognitif yang penting dalam proses belajar mengajar matematika" Untuk mencari penyelesaiannya para siswa harus memanfaatkan pengetahuannya dan melalui proses ini mereka akan sering mengembangkan pemahaman matematika yang baru.

Melalui pengajaran dengan menerapkan Pendekatan Matematika Realistik, kemampuan pemecahan masalah matematika siswa dapat meningkat. Setelah diberikan tindakan pada siklus I diperoleh bahwa tes kemampuan pemecahan masalah I terdapat 24 siswa $(60 \%)$ telah mencapai tingkat ketuntasan belajar, sedangkan 16

Elva Bonica, Hasratuddin, Application of A Realistic Mathematical Approach to Improve The Capacity of The Problem Mathematic Students Class VII SMP Negeri 3 Satu Atap Kuala. Jurnal Inspiratif, Vol. 4, No. 1 April 2018. 
siswa (40\%) belum mencapai tingkat ketuntasan belajar dengan nilai rata-rata kelas 70,83 . Setelah pelaksanaan tindakan pada siklus II pada tes kemampuan pemecahan masalah II, terdapat 37 siswa $(92,5 \%)$ telah mencapai tingkat ketuntasan belajar, sedangkan 3 siswa $(7,5 \%)$ yang belum mencapai tingkat ketuntasan belajar dengan nilai rata-rata kelas 81,83 .
Berdasarkan hasil yang diperoleh menunjukkan bahwa siswa mengalami peningkatan pada nilai rata-rata kelas sebesar 11, yakni dari siklus I 70,83 meningkat menjadi 81,83 pada siklus II. Demikian pula tingkat ketuntasan belajar klasikal meningkat dari $60 \%$ pada siklus I menjadi 92,5\%. Deskripsi tabel kemampuan siswa kelas VII-b setiap siklus.

Tabel 1. Deskripsi kemampuan Siswa

\begin{tabular}{|c|c|c|c|c|}
\hline $\begin{array}{c}\text { Persentase } \\
\text { Penguasaan }\end{array}$ & $\begin{array}{c}\text { Tingkat } \\
\text { Kemampuan }\end{array}$ & Tes Awal & $\begin{array}{c}\text { Siklus I } \\
\text { TKPM-I }\end{array}$ & $\begin{array}{c}\text { Siklus II } \\
\text { TKPM-II }\end{array}$ \\
\hline $90 \%-100 \%$ & Sangat Tinggi & 0 & 1 & 8 \\
\hline $80 \%-89 \%$ & Tinggi & 1 & 8 & 23 \\
\hline $65 \%-79 \%$ & Sedang & 14 & 18 & 6 \\
\hline $55 \%-64 \%$ & Rendah & 10 & 8 & 3 \\
\hline $0 \%-54 \%$ & Sangat Rendah & 15 & 5 & 0 \\
\hline \multicolumn{2}{|r|}{ Jumlah } & 40 & 40 & 40 \\
\hline \multicolumn{2}{|r|}{ Rata-rata Kelas } & 53,75 & 70,83 & 81,83 \\
\hline \multicolumn{2}{|c|}{ Persentase Ketuntasan Klasikal } & $22,5 \%$ & $60 \%$ & $92,5 \%$ \\
\hline \multicolumn{2}{r|}{ Persentase yang tidak tuntas } & $77,5 \%$ & $40 \%$ & $7,5 \%$ \\
\hline
\end{tabular}

Melalui pengajaran dengan menerapkan Pembelajaran konvensional, kemampuan pemecahan masalah matematika siswa dapat meningkat. Setelah diberikan tindakan pada siklus I diperoleh bahwa tes kemampuan pemecahan masalah I terdapat 9 siswa $(22,5 \%)$ telah mencapai tingkat ketuntasan belajar, sedangkan 31 siswa $(77,5 \%)$ belum mencapai tingkat ketuntasan belajar dengan nilai rata-rata kelas 60,167. Setelah pelaksanaan tindakan pada siklus II pada tes kemampuan pemecahan masalah II, terdapat 19 siswa
$(47,5 \%)$ telah mencapai tingkat ketuntasan belajar, sedangkan 21 siswa $(52,5 \%)$ yang belum mencapai tingkat ketuntasan belajar dengan nilai rata-rata kelas 69,08. Berdasarkan hasil yang diperoleh menunjukkan bahwa siswa mengalami peningkatan pada nilai rata-rata kelas sebesar 8,913, yakni dari siklus I 60,167 meningkat menjadi 69,08 pada siklus II. Demikian pula tingkat ketuntasan belajar klasikal meningkat dari $22,5 \%$ pada siklus I menjadi 47,5\%. Deskripsi tabel kemampuan siswa kelas VII-a setiap siklus.

Elva Bonica, Hasratuddin, Application of A Realistic Mathematical Approach to Improve The Capacity of The Problem Mathematic Students Class VII SMP Negeri 3 Satu Atap Kuala. Jurnal Inspiratif, Vol. 4, No. 1 April 2018. 
Tabel 2. Deskripsi Kemampuan Siswa Setiap Siklus

\begin{tabular}{|c|c|c|c|c|}
\hline $\begin{array}{c}\text { Persentase } \\
\text { Penguasaan }\end{array}$ & $\begin{array}{c}\text { Tingkat } \\
\text { Kemampuan }\end{array}$ & Tes Awal & TKPM-I & TKPM-II \\
\hline $90 \%-100 \%$ & Sangat Tinggi & 1 & 0 & 1 \\
\hline $80 \%-89 \%$ & Tinggi & 1 & 5 & 12 \\
\hline $65 \%-79 \%$ & Sedang & 13 & 16 & 16 \\
\hline $55 \%-64 \%$ & Rendah & 11 & 11 & 8 \\
\hline $0 \%-54 \%$ & Sangat Rendah & 14 & 8 & 3 \\
\hline \multicolumn{2}{|c|}{ Jumlah } & 40 & 40 & 40 \\
\hline \multicolumn{2}{|c|}{ Rata-rata Kelas } & 53,75 & 60,167 & 69,08 \\
\hline \multicolumn{2}{|c|}{ Persentase Ketuntasan Klasikal } & $15 \%$ & $22,5 \%$ & $47,5 \%$ \\
\hline \multicolumn{2}{|c|}{ Persentase yang tidak tuntas } & $85 \%$ & $77,5 \%$ & $52,5 \%$ \\
\hline
\end{tabular}

Dari pembahasan di atas, terlihat

Realistik lebih baik daripada Pembelajaran Konvensional. Agar lebih jelas dapat dilihat jelas bahwa Pendekatan Matematika pada tabel sebagai berikut.

Tabel 3. Kemampuan Pemecahan Masalah Matematika Kelas Penelitian

\begin{tabular}{|c|c|c|}
\hline $\begin{array}{c}\text { Tes Pemecahan } \\
\text { Masalah }\end{array}$ & $\begin{array}{c}\text { Pendekatan Matematika } \\
\text { Realistik } \\
\text { VII-b }\end{array}$ & $\begin{array}{c}\text { Pemb Konvensional } \\
\text { VII-a }\end{array}$ \\
\hline Tes Awal & 53,75 & 53,625 \\
\hline TKPM-I & 70,83 & 60,167 \\
\hline TKPM-II & 81,83 & 69,08 \\
\hline
\end{tabular}

Terlihat bahwa pendekatan matematika realistik lebih baik daripada pembelajaran konvensional. Hal ini bisa dilihat dari setiap tes kemampuan pemecahan masalah yang diberi di kelas VII-b yang menerapkan pendekatan matematika realistik dengan kelas VII-a yang menerapkan pembelaajaran konvensional.

\section{KESIMPULAN}

Berdasarkan hasil analisis dan pembahasan dalam penelitian ini, dikemukakan beberapa kesimpulan sebagai berikut:

1. Penerapan Pendekatan Matematika Realistik dapat meningkatkan kemampuan pemecahan masalah matematis siswa kelas VII- SMP Negeri 3 Satu Atap Kuala dengan membagi setiap kelompok terdiri dari 4 orang, memberikan masalah-masalah yang berkaitan dengan dunia nyata yang lebih bervariasi, selalu mengadakan evaluasi dan refleksi pada akhir pembelajaran yang telah dilakukan, sehingga kesulitan yang mempengaruhi keberhasilan pembelajaran baik yang dialami, baik temuan oleh guru maupun siswa pada pembelajaran dapat diatasi dengan sesegera mungkin. Hal ini dapat dilihat dari peningkatan kemampuan pemecahan masalah siswa secara klasikal sebesar $32,5 \%$ dari $60 \%$ pada siklus I meningkat menjadi $92,5 \%$

Elva Bonica, Hasratuddin, Application of A Realistic Mathematical Approach to Improve The Capacity of The Problem Mathematic Students Class VII SMP Negeri 3 Satu Atap Kuala. Jurnal Inspiratif, Vol. 4, No. 1 April 2018. 
pada siklus II. Selain itu, pada siklus I jumlah siswa yang mencapai peningkatan kemampuan pemecahan masalah sebanyak 24 siswa dari 40 siswa pada siklus I meningkat menjadi 37 siswa pada siklus II. Nilai rata-rata kelas 70,83 pada siklus I dan meningkat menjadi 81,83 pada siklus II sehingga diperoleh peningkatan nilai rata-rata kemampuan pemecahan masalah siswa sebesar 11

2. Dengan menerapkan pendekatan matematika realistik dikatakan efektif karena pencapaian ketuntasan belajar siswa secara klasikal meningkat, pada siklus I ketuntasan belajar siswa secara klasikal sebesar 60\% sebanyak 24 siswa dari 40 siswa tuntas dan sebesar $40 \%$ sebanyak 16 siswa tidak tuntas sedangkan pada siklus II ketuntasan belajar siswa secara klasikal sebesar 92,5\% sebanyak 37 siswa dari 40 siswa tuntas dan sebesar $7,5 \%$ sebanyak 3 siswa tidak tuntas.

3. Hasil kemampuan pemecahan masalah matematika siswa yang diajar dengan Pendekatan Matematika Realistik diperoleh rata-rata sebesar 81,83 sedangkan hasil kemampuan pemecahan masalah matematika siswa yang diajar dengan pembelajaran Konvensional diperoleh rata-rata sebesar 69,08.

\section{DAFTAR PUSTAKA}

Abdurrahman, M., (2009), Pendidikan Bagi Anak Berkesulitan Belajar, Rineka Cipta, Jakarta

Amalia,E., Surya,E., \& Syahputra, E., (2017). The Effectiveness Of Using Problem Based Learning (PBL) In Mathematics Problem Solving Ability For Junior High School Students. International Journal of Advance Research And Innovative Ideas InEducation (IJARIIE). Vol.3, Issue-2. https://www.researchgate.net/publica tion/318982082
Aqib, Z., (2009), Penelitian Tindakan Kelas, Yrama Widya, Bandung

Bakri, A., 2012, Masalah Dalam Matematika, http://masalah-dalammatematika.html, (diakses Februari 2017)

Batubara,N.F, dkk. (2017). Analysis Of Student Mathematical Problem Solving Skills At Budi Satrya of Junior High School. International Journal Of Advance Research And Innovative Ideas In Education. Vol. 3, issu.2, pp: (2170-2173), Available at: www.ijariie.com

Dewi, R., (2015), Profesionalisasi Guru Melalui Penelitian Tindakan Kelas, UNIMED Press, Medan

Erna, M., (2016), Penerapan Pendekatan Matematika Realistik Untuk Meningkatkan Kemampuan Representasi Matematis Siswa, Vol. 10 No. 2

Fathurrohman, M., (2015), Model-model pembelajaran Inovatif Alternatif Desain Pembelajaran yang Menyenangkan, Ar-Ruzz Media, Jogjakarta

Hasanah,M., \& Surya,E. (2017). Differences in the Abilities of Creative Thinking and Problem Solving of Students in Mathematics by Using Cooperative Learning and Learning of Problem Solving. International Journal of Sciences: Basic and Applied Research (IJSBAR). Volume 34, No 1, pp 286-299.

https://www.researchgate.net/public ation/318561310

Hasratuddin, (2015), Mengapa Harus Belajar Matematika, Perdana Publishing, Medan

Hia, Y., (2013), Penerapan Model Pembelajaran Kooperatif Tipe

Elva Bonica, Hasratuddin, Application of A Realistic Mathematical Approach to Improve The Capacity of The Problem Mathematic Students Class VII SMP Negeri 3 Satu Atap Kuala. Jurnal Inspiratif, Vol. 4, No. 1 April 2018. 
Jigsaw Untuk Meningkatkan Aktivitas dan Hasil Belajar Matematika Siswa Kelas VIII, Jurnal Generasi Kampus, Vol. 6, No.2. 2013 ISSN: 1978-869X. (diakses 06 Maret 2017)

Hudojo, H., (2005), Pengembangan Kurikulum dan Pembelajaran Matematika, Universitas Negeri Malang, Malang

Husna, R., dkk., Peningkatan Kemampuan Pemecahan Masalah dan Komunikasi Matematik Melalui Pendekatan Matematika Realistik Pada Siswa SMP Kelas VII Langsa, Vol. 6 No. 2, Hal 175-186

Mawaddah, S., (2015), Kemampuan Pemecahan Masalah Matematis Siswa Pada Pembelajaran Matematika Dengan Menggunakan Model Pembelajaran Generatif (Generative Learning) Di Smp, Jurnal Pendidikan Matematika. Vol 3. No.2 .

National Council of Teachers of Mathematics, (2000), Principles Standards and for School Mathematics, Reston, VA, NCTM

Peranginangin,S.A., \& Surya, E. (2017). An Analysis of Students, Mathematics Problem Solving Ability in VII Grade at SMP Negeri 4 Pancurbatu. International Journal of Sciences: Basic and Applied Research (IJSBAR). Vol.33, No.2, https://www.researchgate.net/publica tion/317577870

Polya, G., (1973), How to Solve it, A New Aspect of Mathematical Method, Princeton University Press, Princeton.

Rizqi, N.R. and Surya, E. (2017). An Analysis of Students' Mathematical Reasoning Ability In VIII Grade of Sabilina
Tembung Junior High School, IJARIIE, ISSN(O)-2395-4396, 3(2), 3527-3533.

Rosita, D., (2009), Penunjang Belajar Matematika Untuk SMP/MTS, CV. Sari Ilmu Pratama, Jakarta

Slameto, (2013), Belajar dan FaktorFaktor yang Mempengaruhi, Rineka Cipta, Jakarta

Sugiman, (2010), Dampak Pendidikan Matematika Realistik Terhadap Peningkatan Kemampuan Pemecahan Masalah Siswa SMP, Vol. 1 No. 1, Hal 41-51

Suhendar, U., (2016), Pengembangan Modul Materi Statistik berbasis Pendekatan PMR Bagi Siswa SMK Kelas XI, Jurnal Silogisme. Vol. 1, No.1. ISSN: 2527-6182.

Surya, E. Putri, F.A. and Mukhtar. 2017. Improving Mahematical Problem Solving Ability and SelfConfidence of High School Students Through Contextual Learning Model. Indonesian Mathematical Society Journal on Mathematics Education, 8(1), 8594.

Trianto, (2009), Mendesain Model Pembelajaran Inovatif-Progresif, Kencana, Jakarta

, (2011), Mendesain Model Pembelajaran Inovatif-Progresif, Konsep Landasan, Dan Implementasinya Pada Kurikulum Tingkat Satuan Pendidikan (KTSP), Kencana, Jakarta

Warli, (2010), Pembelajaran Matematika realistik Materi Geometri Kelas IV $M I$. ,http://ejournal.unirow.ac.id/oj

Elva Bonica, Hasratuddin, Application of A Realistic Mathematical Approach to Improve The Capacity of The Problem Mathematic Students Class VII SMP Negeri 3 Satu Atap Kuala. Jurnal Inspiratif, Vol. 4, No. 1 April 2018. 
s/files/journals/2/articles/4/public/ JURNAL-WARLI-4.pdf. (diakses Januari 2017)
Alternatif

Pendekatan

Pembelajaran Matematika, Graha Ilmu, Yogyakarta

Wijaya, A., (2012), Pendidikan

Matematika Realistik Suatu 